EXTENDED REPORT

\title{
Early effects of tumour necrosis factor $\alpha$ blockade on skin and synovial tissue in patients with active psoriasis and psoriatic arthritis
}

\author{
A Y Goedkoop, M C Kraan, M B M Teunissen, D I Picavet, M A de Rie, J D Bos, P P Tak
}

Ann Rheum Dis 2004;63:769-773. doi: 10.1136/ard.2003.018085

See end of article for authors' affiliations

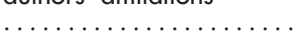

Correspondence to: Professor P P Tak, Division of Clinical Immunology and Rheumatology, F4-218, Academic Medical Centre/University of Amsterdam, Meibergdreef' 9 , NL-1 105 AZ Amsterdam, The Netherlands; P.P.Tak@ amc.uva.nl

Accepted 9 January 2004

\begin{abstract}
Background: Tumour necrosis factor $\alpha$ (TNF $\alpha$ ) blockade using infliximab, a chimeric anti-TNF $\alpha$ antibody, is an effective treatment for both psoriasis and psoriatic arthritis (PsA).

Objective: To analyse the early effects of infliximab treatment on serial skin and synovial tissue biopsy samples.

Methods: Twelve patients with both active psoriasis and PsA received a single infusion of either infliximab $(3 \mathrm{mg} / \mathrm{kg})(\mathrm{n}=6)$ or placebo $(\mathrm{n}=6)$ intravenously. Synovial tissue and lesional skin biopsy specimens were obtained at baseline and 48 hours after treatment. Immunohistochemical analysis was performed to analyse the inflammatory infiltrate. In situ detection of apoptotic cells was performed by TUNEL assay and by immunohistochemical staining with anti-caspase-3 antibodies. Stained tissue sections were evaluated by digital image analysis.

Results: A significant reduction in mean (SEM) T cell numbers was found in both lesional epidermis (baseline 37 (11) cells $/ \mathrm{mm}, 48$ hours 26 (11), $\mathrm{p}=0.028$ ) and synovial tissue $\left(67\right.$ (56) cells $/ \mathrm{mm}^{2} \vee 32$ (30), $p=0.043$ ) after infliximab treatment, but not after placebo treatment (epidermis 18 (8) v 43 (20), NS; synovium 110 (62) v 46 (21), NS). Similarly, the number of macrophages in the synovial sublining was significantly reduced after anti-TNF $\alpha$ treatment $(100(73) \vee 10(8), p=0.043)$. The changes in cell numbers could not be explained by induction of apoptosis at the site of inflammation.

Conclusions: The effects of anti-TNF $\alpha$ therapy in psoriasis and psoriatic arthritis may be explained by decreased cell infiltration in lesional skin and inflamed synovial tissue early after initiation of treatment.
\end{abstract}

$\mathrm{T}$ umour necrosis factor $\alpha(\mathrm{TNF} \alpha)$ is a pivotal cytokine in various chronic inflammatory disorders, including rheumatoid arthritis (RA) and Crohn's disease. The central role of this cytokine has been emphasised by the therapeutic efficacy of infliximab, a chimeric TNF $\alpha$ neutralising antibody. ${ }^{1-3}$

Psoriasis is a common dermatological disorder, affecting approximately $1.5 \%$ of the population, and is characterised by epidermal hyperproliferation, increased dermal angiogenesis, and infiltration of mononuclear cells into the dermis and epidermis. Psoriatic arthritis (PsA) affects $5-40 \%$ of the patients with psoriasis, and is diagnosed by clinical signs and symptoms, such as absence of rheumatoid factor, and a presentation of asymmetric, oligoarticular, axial, and/or distal interphalangeal joint involvement. ${ }^{4}$ Like RA, PsA can cause considerable joint damage, disability, and impairment of the quality of life in a significant proportion of patients, with the additional handicap of skin involvement. The synovium of patients with PsA has not been studied as extensively as that of patients with RA. Recent studies suggest that the histology shows both differences and similarities between the two inflammatory joint diseases. ${ }^{56}$ The cell infiltrate in both joint diseases is composed predominantly of CD3+ T lymphocytes, located around the small blood vessels and near the hyperplastic intimal lining layer. Other cell types found in the synovial tissue of patients with PsA include macrophages and some neutrophils, located near the intimal lining layer and around the blood vessels. ${ }^{7}$

Although the cause of psoriasis and PsA is still unknown, increasing evidence shows that the inflammatory response is primarily initiated by activated $\mathrm{T}$ cells in the epidermis and dermis of psoriatic lesions and in the synovium of affected joints. ${ }^{8-11}$ Proinflammatory cytokines, such as TNF $\alpha$, have a key role in the inflammatory cascade in psoriasis and PsA as illustrated by the increased TNF $\alpha$ expression in psoriatic skin lesions ${ }^{12}{ }^{13}$ and inflamed synovial tissue. ${ }^{14}{ }^{15}$ Consistent with this notion, infliximab has been reported to be clinically effective for both psoriasis and PsA, ${ }^{16-20}$ but the mechanism of action is not precisely known. To provide more insight into the effects of infliximab treatment in psoriasis and PsA, we performed a single centre, randomised, placebo controlled study to investigate the early changes at the site of inflammation.

\section{PATIENTS AND METHODS \\ Patients}

Twelve patients with both active skin disease and active joint inflammation, diagnosed with PsA at least 12 months before inclusion, were evaluated in this prospective, single centre, double blind, randomised, placebo controlled study. Active arthritis was defined as at least three tender joints ( 28 joint count and both ankles ${ }^{21}$ ), and physician's and patient's joint assessment as moderate or worse, despite concurrent methotrexate (MTX) treatment at maximal tolerable dose (5-20 mg/week). Active psoriasis was defined as at least two psoriatic plaques. The dose of MTX was kept stable at least 28 days before inclusion in the study. Stable doses of nonsteroidal anti-inflammatory drugs were allowed, but prednisolone therapy was not. Only patients with a swollen knee or wrist joint were included. After randomisation patients received a single infusion of infliximab $3 \mathrm{mg} / \mathrm{kg}$ or placebo.

All patients gave informed consent before inclusion, and the study protocol was reviewed and approved by medical ethics committee of the Academic Medical Centre/University

Abbreviations: MTX, methotrexate; $\mathrm{PsA}$, psoriatic arthritis; RA, rheumatoid arthritis; TNF $\alpha$, tumour necrosis factor $\alpha$ 
of Amsterdam. The study was conducted according to the Declaration of Helsinki principles.

\section{Synovial biopsies}

At baseline and 48 hours after infusion of either infliximab or placebo, small bore arthroscopy was performed under local anaesthesia of the same knee $(n=8)$ or wrist $(n=4)$ joint. An average of at least 12 synovial tissue samples was obtained from the entire joint using a $2.5 \mathrm{~mm}$ grasping forceps (Storz, Tuttlingen, Germany) on each occasion, as described previously. ${ }^{22}$ Six samples were fixed in formaldehyde and embedded in paraffin, six samples were snap frozen en bloc in Tissue Tek OCT (Miles, Elkhart, IN) and stored in liquid nitrogen until sectioning. Sections $(5 \mu \mathrm{m})$ were cut in a cryostat and mounted on glass slides (Star Frost adhesive slides; Knittelgläser, Germany), which were stored at $-70^{\circ} \mathrm{C}$ until immunohistochemical analysis could be performed.

\section{Skin biopsies}

At baseline and 48 hours after infusion with either infliximab or placebo, $4 \mathrm{~mm}$ punch biopsies were taken from the inside border of a target psoriatic plaque, preferentially from an area not exposed to sun. Biopsy samples from each individual patient were obtained from the same target lesion, separated by at least $1 \mathrm{~cm}$. The samples were randomly coded, snap frozen in Tissue Tek OCT (Sakura Finetek Europe, Zoeterwoude, The Netherlands), and stored at $-70^{\circ} \mathrm{C}$ until further processing. Cryostat sections $(5 \mu \mathrm{m})$ were cut and mounted on glass slides (Star Frost adhesive slides), and stored at $-70^{\circ} \mathrm{C}$ until immunohistochemical staining.

\section{Immunohistochemistry}

The synovium and skin sections were stained with the monoclonal antibodies anti-CD3 (Becton Dickinson, San Jose, CA) to detect $\mathrm{T}$ lymphocytes, and anti-caspase-3 (Pharmingen, Becton Dickinson (skin), Cell Signaling Technology, Leusden, The Netherlands (synovium)) to detect apoptotic cells. In addition, the synovial tissue was stained with anti-CD68 (clone EBM11; Dako, Glostrup, Denmark) to detect macrophages. The staining procedure was performed as described previously. ${ }^{23}$ After a primary incubation step with monoclonal antibodies, bound antibody was detected according to a three step immunoperoxidase method. Horseradish peroxidase activity was detected using hydrogen peroxide as substrate and amino-ethylcarbazole as dye, producing a reddish colour.

\section{TUNEL assay}

A TUNEL assay was performed according to the manufacturer's instructions (Roche, Mannheim, Germany). In short, apoptotic cells in frozen synovial tissue or skin tissue were detected by terminal deoxynucleotidyl transferase-mediated dUTP nick end labelling of apoptosis induced DNA strand breaks, using in situ cell death detection assay.

\section{Digital image analysis}

All sections were randomly coded and analysed by computer assisted image analysis, as previously described in detail. ${ }^{24}$ For the synovial tissue samples, three separate regions of six high power fields $\left(2.1 \mathrm{~mm}^{2}\right)$ were evaluated. Macrophage (CD68) expression was analysed separately in the intimal lining layer and the synovial sublining. Caspase-3 expression was measured as integrated optical density, a product of staining area and intensity.

For the skin tissue samples, one single region of 20 high power fields $\left(2.1 \mathrm{~mm}^{2}\right)$ including both epidermis and dermis was analysed. The images were acquired and analysed using Syndia algorithm on a Qwin based analysis system (Leica, Cambridge, UK), as described previously.

\section{Statistical analysis}

SPSS 10.1.4 for Windows (SPSS, Chicago, IL) was used for statistical analysis. The Wilcoxon signed rank test for matched pairs was used to compare data within each group. Results were expressed as mean (SEM).

\section{RESULTS}

\section{Patient characteristics}

Six men and six women were included in the study, and randomly allocated to receive either infliximab or placebo. Clinical baseline characteristics in both groups were comparable (table 1). From one of the patients, skin biopsy samples were not obtained for technical reasons. From another patient included in the study, the synovial tissue biopsy at baseline was not eligible for immunohistochemical analysis for quality reasons and, therefore, all samples from this patient were excluded from analysis.

\section{Immunohistochemical analysis}

The severity of the inflammatory infiltrate in lesional epidermis and synovial tissue was comparable in both treatment groups at baseline. Forty eight hours after infusion, a significant reduction in the number of epidermal $\mathrm{T}$ cells was seen in patients treated with infliximab (baseline 37 (11) cells $/ \mathrm{mm}, 48$ hours 26 (11), p=0.028), in contrast with patients treated with placebo ( $18(8) \vee 43$ (20), NS). This observation was mirrored by analysis of synovial tissue, showing a decrease in the total number of T cells 48 hours after treatment with infliximab (67 (56) cells $/ \mathrm{mm}^{2} v 32$ (30), $\mathrm{p}=0.043)$, but no significant change in the placebo group (110 (62) v $46(21)$, NS). Analysis of the synovial sublining also showed a significant reduction in the number of sublining macrophages in infliximab treated patients (100 (73) $v 10(8), \mathrm{p}=0.043)$, but not in the control group (111 (41) $v 67$ (20), NS). The decrease in macrophages in the intimal lining layer did not reach significance (infliximab 48 (41) v 5 (3), NS; placebo 81 (25) v 53 (36), NS). Figures 1 and 2 and table 2 show the changes in the inflammatory infiltrate in both treatment groups.

\section{Apoptosis assays}

The presence of apoptotic cells was determined by TUNEL assay. Sections treated with DNase (Roche) to induce DNA fragmentation were included as positive controls.

Of interest, 48 hours after baseline, the number of apoptotic cells in both skin and synovium was unaltered in both the infliximab group (epidermis: baseline 12 (7) cells/ $\mathrm{mm}, 48$ hours 10 (6); synovium: baseline 28 (10) cells $/ \mathrm{mm}^{2}$, 48 hours 22 (10), NS) and the placebo group (epidermis: baseline 33 (13), 48 hours 45 (26); synovium: baseline 58 (20), 48 hours 43 (14), NS) (fig 2). To exclude the possibility of

Table 1 Baseline characteristics

\begin{tabular}{lll}
\hline & Infliximab (n=6) & Placebo $(\mathbf{n}=6)$ \\
\hline Age & $53(35-70)$ & $45(26-60)$ \\
Male: female & $3: 3$ & $3: 3$ \\
Duration of joint disease (years) & $9(5-13)^{*}$ & $9(1-22)$ \\
Duration of skin disease (years) & $24(10-41)$ & $17(2-38)^{*}$ \\
DAS & $6.8(5.0-7.9)^{*}$ & $5.7(4.8-8.2)$ \\
30 Tender joint count & $19(2-26)^{*}$ & $9(2-25)$ \\
30 Swollen joint count & $15(9-21)^{*}$ & $7(2-26)$ \\
VAS & $81(65-90)^{*}$ & $68(36-93)$ \\
CRP & $23(10-36)^{*}$ & $28(7-65)$ \\
PASI & $13.7(1-29.8)$ & $10.5(5-19.0)^{*}$ \\
MTX dose (mg/week) & $10(5-20)$ & $10(5-20)$ \\
\hline \multirow{2}{*}{$n=5}$. & & \\
DAS, Disease Activity Score; VAS, visual analogue scale; CRP, C reactive \\
protein; PASI, Psoriasis Area and Severity Index; MTX, methotrexate. \\
Results are shown as mean (range).
\end{tabular}




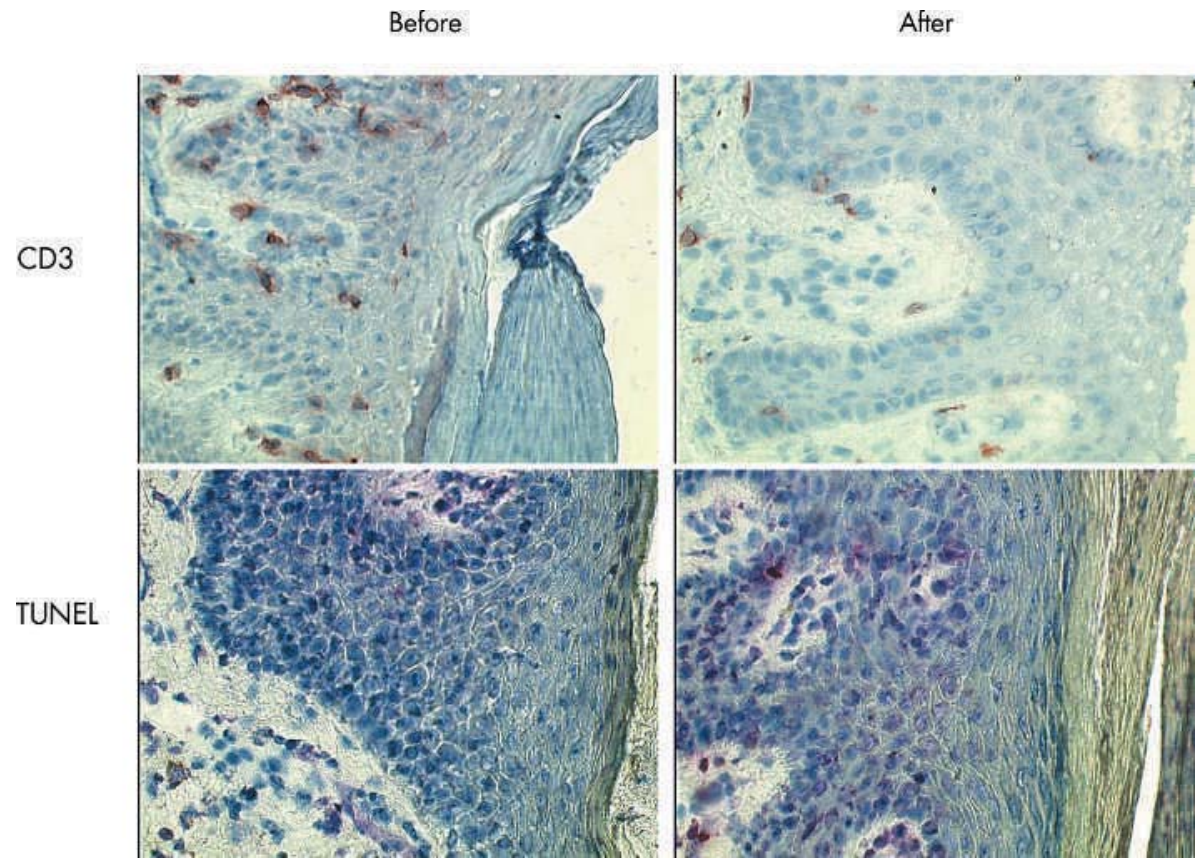

Figure 1 Representative images of CD3+ immunohistochemical staining and TUNEL assay in lesional psoriatic skin at baseline and 48 hours after initiation of infliximab treatment. Original magnification $\times 400$.

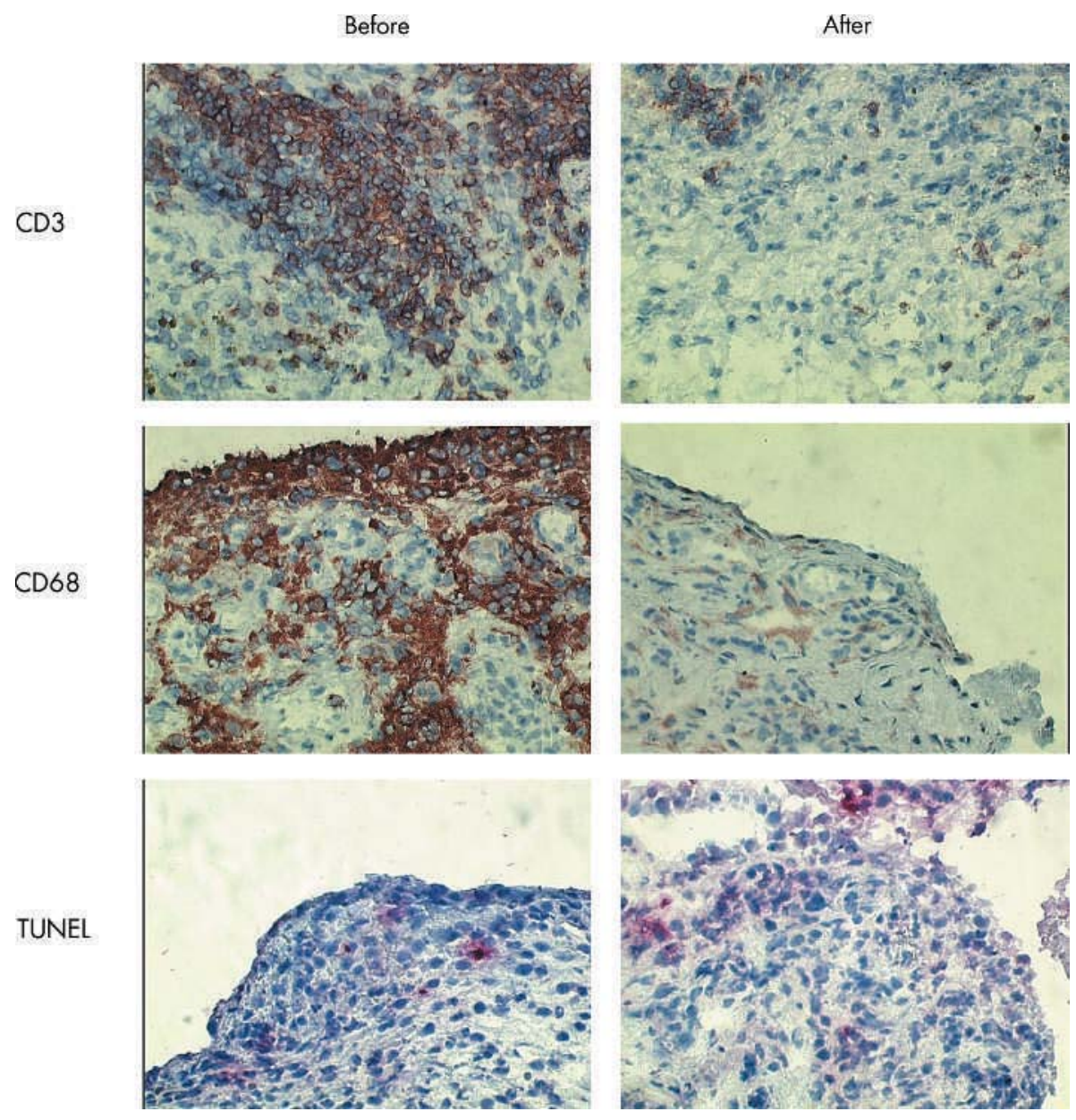

Figure 2 Representative images of CD3+ and CD68+ immunohistochemical staining and TUNEL assay in synovial tissue at baseline and 48 hours after initiation of infliximab treatment. Original magnification $\times 400$. 
Table 2 Results of immunohistochemical staining and TUNEL assay of lesional skin and synovial biopsies

\begin{tabular}{|c|c|c|c|c|}
\hline & \multicolumn{2}{|c|}{ Infliximab $3 \mathrm{mg} / \mathrm{kg}$} & \multicolumn{2}{|l|}{ Placebo } \\
\hline & Before & After & Before & After \\
\hline $\mathrm{CD}^{+}$epidermis & 37 (11) & $26(11)^{*}$ & $18(8)$ & $43(20)$ \\
\hline $\mathrm{CD}^{+}$dermis & $159(84)$ & $136(54)$ & $101(34)$ & $167(54)$ \\
\hline $\mathrm{CD}^{+}$synovium & $67(56)$ & $32(30)^{*}$ & $110(62)$ & $46(21)$ \\
\hline $\mathrm{CD} 8^{+}$intimal lining layer & $48(41)$ & 5 (3) & $81(25)$ & $53(36)$ \\
\hline $\mathrm{CD} 8^{+}$synovial sublining & $100(73)$ & $10(8)^{*}$ & $111(41)$ & $67(20)$ \\
\hline TUNEL $^{+}$epidermis & $12(7)$ & $10(6)$ & 33 (13) & $45(26)$ \\
\hline TUNEL $^{+}$synovium & $28(10)$ & $22(10)$ & $58(20)$ & 43 (14) \\
\hline
\end{tabular}

*Significant reduction from baseline, $\mathrm{p}<0.05$

Epidermal counts are given as positive cells $/ \mathrm{mm}$. Dermal and synovial counts are given as positive cells $/ \mathrm{mm}^{2}$.

Results are expressed as mean (SEM).

a false negative result as a consequence of decreased cellularity, the analysis was repeated after correction for total cell counts. This confirmed that the number of TUNEL positive cells was not increased after treatment (data not shown).

Skin sections and synovial tissue were also analysed for caspase-3 expression, as a marker of apoptosis. As positive controls, sections from UVB treated psoriatic skin were included, which clearly showed increased capsase-3 expression. Consistent with data obtained by TUNEL assay, the expression of caspase-3 did not significantly change after treatment in either group (data not shown).

\section{DISCUSSION}

The data presented in this study show that a single infusion of a relatively low dose of infliximab $(3 \mathrm{mg} / \mathrm{kg})$ significantly decreases $\mathrm{T}$ cell and macrophage infiltration in synovial tissue of patients with PsA 48 hours after treatment. Similarly, we observed a reduction in $\mathrm{T}$ cell numbers in lesional epidermis. The reductions in the cell infiltrate could not be explained by an increase in the number of apoptotic cells at the site of inflammation.

Theoretically, the effects reported here might be influenced to some extent by the concurrent treatment with MTX. This drug may be capable of inhibiting synovial cell infiltration, in part by reducing the expression of adhesion molecules in synovial tissue. ${ }^{25}$ However, all patients had active disease at the time of inclusion despite MTX, and doses were kept stable at least 28 days before the start and during the study. Therefore, it appears unlikely that concomitant MTX treatment had a significant effect on the changes in synovial and skin biopsy samples. This notion is supported by the absence of significant changes in the patients who received placebo who also continued MTX treatment.

For analysis of synovial tissue we chose to select infiltration by $\mathrm{T}$ cells and macrophages because both cell types are considered crucial players in the pathogenesis of synovial inflammation in PsA. Moreover, previous work in patients with RA has shown a reduction in numbers of $\mathrm{T}$ cells ${ }^{26}$ and macrophages ${ }^{27} 2-4$ weeks after a single infusion of $10 \mathrm{mg} / \mathrm{kg}$ infliximab, suggesting that $\mathrm{TNF} \alpha$ blockade might exert its effects, in part, by targeting these cells in the synovium, at least in RA. The a priori restriction of the number of immunohistological variables obviously decreases the chance of erroneously reporting statistically significant effects due to multiple comparisons.

The significant decrease in inflammatory cell infiltration in synovial tissue demonstrated in the present study is consistent with the reduction in synovial inflammation shown by gadolinium-DTPA uptake at week 10, which was previously described in patients with PsA who received infliximab treatment at $5 \mathrm{mg} / \mathrm{kg}$ at weeks 0,2 , and $6 .^{28}$ In addition, an open study in a heterogeneous group of eight patients with spondyloarthropathy treated with infliximab at $5 \mathrm{mg} / \mathrm{kg}$ according to the same regimen showed a decrease in synovial macrophage infiltration 12 weeks after initiation of treatment. ${ }^{29}$ The infliximab dose used in the present study $(3 \mathrm{mg} / \mathrm{kg}$ ) is markedly lower than that used in previous studies evaluating the effects of infliximab in psoriasis and PsA. The results suggest that the lower dose may also be effective. Obviously, clinically meaningful effects remain to be shown in larger, clinical studies.

In line with the changes in the synovium, we describe a decrease in $\mathrm{T}$ cell infiltration in paired skin biopsy samples after infliximab treatment. $\mathrm{T}$ cells are believed to have a central role in the pathogenesis of psoriasis, based on the presence of $\mathrm{T}$ cells in early psoriasis lesions, ${ }^{30}$ the beneficial effects of $\mathrm{T}$ cell targeted treatments like cyclosporin ${ }^{31}$ and alefacept, ${ }^{32}$ and the altered relation between psoriatic keratinocytes and interferon $\gamma$ compared with normal keratinocytes. ${ }^{33}$ It is tempting to speculate that a decrease in antigen driven $T$ cells at the site of inflammation may explain, in part, the beneficial effect of anti-TNF treatment in patients with psoriasis, similar to the effects of biologic therapies specifically targeting activated T cells in psoriasis and PsA. ${ }^{11}{ }^{32}$

The changes in skin and synovial tissue were detected very early after initiation of treatment. Similar results were recently reported in patients with RA treated with infliximab. ${ }^{34}$ Consistent with the early immunohistological changes is the sometimes rapid onset of clinical improvement and changes in the acute phase response in patients with inflammatory disorders treated with infliximab. Clinical improvement and a reduction in $\mathrm{C}$ reactive protein levels may occur as early as 48 hours after the start of treatment. ${ }^{2035} 36$

In line with recent observations in RA synovium, ${ }^{34}$ the decrease in cell infiltration could not be explained by induction of apoptosis at the site of inflammation, as shown by both TUNEL assay and caspase- 3 staining. Thus, it appears that the mechanism of action of infliximab therapy might differ between RA, PsA, and psoriasis, on the one hand, and Crohn's disease,,$^{37}$ on the other. In the last condition an increase in the number of apoptotic cells in the lamina propria of the gut has been detected after infliximab therapy. A possible explanation for the discrepancy might be the difference in disease pathogenesis and tissue-specific properties. Neutralisation of the effects of TNF $\alpha$ appears sufficient to induce clinical improvement in RA, PsA, and psoriasis even without induction of apoptosis at the site of inflammation. It should be noted that the available data suggest that treatment with both anti-TNF $\alpha$ antibodies and soluble TNF receptors are equally effective in RA, PsA, and psoriasis ${ }^{39} 40$ but not in Crohn's disease, ${ }^{41}$ where induction of apoptosis by anti-TNF antibody may be the key to inducing clinical improvement. 
The decrease in cell infiltration seen in both skin and synovial tissue might be explained by reduced cell trafficking after TNF $\alpha$ blockade. Studies in patients with RA have shown that infliximab treatment decreases expression of adhesion molecules ${ }^{26}$ and chemokines, ${ }^{27}$ molecules that are intimately involved in cell migration. Detailed studies examining the effects of anti-TNF treatment on cell trafficking in PsA and psoriasis are, as yet, not available. In addition, we cannot exclude the possibility that infliximab may induce apoptosis in compartments other than skin and synovium, such as the bone marrow and peripheral blood, thereby affecting migration of inflammatory cells towards the synovial compartment and the skin. This remains to be shown in future studies.

In conclusion, this study demonstrates a significant reduction in cell infiltration in both lesional epidermis and synovial tissue of patients with PsA by 48 hours after a single infusion of infliximab. The data support the view that TNF $\alpha$ is one of the key mediators in both psoriasis and PsA.

\section{Authors' affiliations}

A Y Goedkoop, M C Kraan, P P Tak, Division of Clinical Immunology and Rheumatology, Department of Internal Medicine, Academic Medical Centre/University of Amsterdam, Amsterdam, The Netherlands A Y Goedkoop, M B M Teunissen, D I Picavet, M A de Rie, J D Bos, Department of Dermatology, Academic Medical Centre/University of Amsterdam, Amsterdam, The Netherlands

\section{REFERENCES}

1 Lipsky PE, van der Heijde DM, St Clair EW, Furst DE, Breedveld FC, Kalden JR, et al. Infliximab and methotrexate in the treatment of rheumatoid arthritis. Anti-Tumor Necrosis Factor Trial in Rheumatoid Arthritis with Concomitant Therapy Study Group. N Engl J Med 2000;343:1594-602.

2 Maini R, St Clair EW, Breedveld F, Furst D, Kalden J, Weisman M, et al. ATTRACT Study Group. Infliximab (chimeric anti-tumour necrosis factor alpha monoclonal antibody) versus placebo in rheumatoid arthritis patients receiving concomitant methotrexate: a randomized phase III trial. Lancet 1999;354:1932-9.

3 Present DH, Rutgeerts P, Targan S, Hanauer SB, Mayer L, van Hogezand RA, et al. Infliximab for the treatment of fistulas in patients with Crohn's disease. N Engl J Med 1999;340:1398-405.

4 Espinoza LR, Cuellar ML, Silveira LH. Psoriatic arthritis. Curr Opin Rheumatol 1992;4:470-8.

5 Reece RJ, Canete JD, Parsons WJ, Emery P, Veale DJ. Distinct vascular patterns of early synovitis in psoriatic, reactive, and rheumatoid arthritis. Arthritis Rheum 1999:42:1481-4.

6 Veale D, Yanni G, Rogers S, Barnes L, Bresnihan B, FitzGerald O. Reduced synovial membrane macrophage numbers, ELAM-1 expression, and lining layer hyperplasia in psoriatic arthritis as compared with rheumatoid arthritis Arthritis Rheum 1993;36:893-900.

7 Konig A, Krenn V, Gillitzer R, Glockner J, Janssen E, Gohlke F, et al. Inflammatory infiltrate and interleukin-8 expression in the synovium of psoriatic arthritis-an immunohistochemical and mRNA analysis. Rheumatol Int 1997; 17:159-68

8 Bos JD, Hulsebosch HJ, Krieg SR, Bakker PM, Cormane RH. Immunocompetent cells in psoriasis. In situ phenotyping by monoclonal antibodies. Arch Dermatol Res 1983;275:181-9.

9 Gottlieb SL, Gilleaudeau P, Johnson R, Estes L, Woodworth TG, Gottlieb AB, et al. Response of psoriasis to a lymphocyte-selective toxin (DAB389IL-2) suggests a primary immune, but not keratinocyte, pathogenic basis. Nat Med 1995; 1:442-7.

10 Costello PJ, Winchester RJ, Curran SA, Peterson KS, Kane DJ, Bresnihan B, et al. Psoriatic arthritis joint fluids are characterized by CD8 and CD4 T cell clona expansions that appear antigen driven. J Immunol 2001;166:2878-86.

11 Kraan MC, van Kuijk AWR, Dinant HJ, Goedkoop AY, Smeets TJM, de Rie MA, et al. Alefacept treatment in psoriatic arthritis: reduction of the effector $T$ cell population in peripheral blood and synovial tissue is associated with improvement of clinical signs of arthritis. Arthritis Rheum 2002:46:2776-84.

12 Ettehadi P, Greaves W, Wallach D, Aderka D, Camp RD. Elevated tumor necosis factor-alpha (TNF-alpha) biological activity in psoriatic skin lesions. Clin Exp Immunol 1994;96: 146-51.

13 Bonifati C, Carducci M, Cordiali-Fei P, Trento E, Sacerdoti G, Fazio M, et al. Correlated increases of tumor necrosis factor-alpha, interleukin- 6 and granulocyte monocyte-colony stimulating factor levels in suction blister fluids and sera of psoriatic patients: relationships with disease severity. Clin Exp Dermatol 1994;19:383-7.

14 Partsch G, Steiner G, Leeb BF, Dunky A, Broll H, Smolen JS. Highly increased levels of tumor necrosis factor- $\alpha$ and other proinflammatory cytokines in psoriatic arthritis synovial fluid. J Rheumatol 1997;24:518-23.

15 Ritchlin C, Haas-Smith SA, Hicks D, Cappuccio J, Osterland CK, Looney RJ. Patterns of cytokine production in psoriatic synovium. J Rheumatol 1998;25:1544-52.
16 Oh CJ, Das KM, Gottlieb AB. Treatment with anti-tumor necrosis factor $\alpha$ (TNF- $\alpha$ ) monoclonal antibody dramatically decreases the clinical activity of psoriasis lesions. J Am Acad Dermatol 2000;42:829-30.

17 Chaudhari U, Romano P, Mulcahy LD, Dooley LT, Baker DG, Gottlieb AB. Efficacy and safety of infliximab monotherapy for plaque-type psoriasis: a randomised trial. Lancet 2001;357:1842-7.

18 Ogilvie AL, Antoni C, Dechant C, Manger B, Kalden JR, Schuler G, et al. Treatment of psoriatic arthritis with antitumour necrosis factor-alpha antibody clears skin lesions of psoriasis resistant to treatment with methotrexate. Br J Dermatol 2001; 144:587-9.

19 Wollina U, Konrad H. Treatment of recalcitrant psoriatic arthritis with antitumor necrosis factor- $\alpha$ antibody. J Eur Acad Dermatol Venereol 2002;16:127-9.

20 Gottlieb AB, Masud S, Ramamurthi R, Abdulghari A, Romano P, Chaudhari U, et al. Pharmacodynamic and pharmacokinetic response to anti-tumor necrosis factor- $\alpha$ monoclonal antibody (infliximab) treatment of moderate to severe psoriasis vulgaris. J Am Acad Dermatol 2003;48:68-75.

21 Smolen JS, Breedveld FC, Eberl G, Jones I, Leeming M, Wylie GL, et al. Validity and reliability of the twenty-eight-joint count for the assessment of rheumatoid arthritis activity. Arthritis Rheum 1995;3:38-43.

22 Kraan MC, Reece RJ, Smeets TJ, Veale DJ, Emery P, Tak PP. Comparison of synovial tissues from the knee joints and the small joints of rheumatoid arthritis patients: implications for pathogenesis and evaluation of treatment. Arthritis Rheum 2002;46:2034-8.

23 Tak PP, van der Lubbe PA, Cauli A, Daha MR, Smeets TJM, Kluin PM, et al. Reduction of synovial inflammation after anti-CD4 monoclonal antibody treatment in early rheumatoid arthritis. Arthritis Rheum 1995:38:1457-65.

24 Kraan MC, Haringman JJ, Ahern MJ, Breedveld FC, Smith MD, Tak PP. Quantification of the cell infiltrate in synovial tissue by digital image analysis. Rheumatology (Oxford) 2000;39:43-9.

25 Dolhain RJEM, Tak PP, Dijkmans BAC, de Kuiper P, Breedveld FC Miltenburg AMM. Methotrexate treatment reduces inflammatory cell numbers, expression of monokines and of adhesion molecules in synovial tissue of patients with rheumatoid arthritis. Br J Rheumatol 1998;37:502-8.

26 Tak PP, Taylor PC, Breedveld FC, Smeets TJ, Daha MR, Kluin PM, et al. Decrease in cellularity and expression of adhesion molecules by anti-tumor necrosis factor alpha monoclonal antibody treatment in patients with rheumatoid arthritis. Arthritis Rheum 1996;39:1077-81

27 Taylor PC, Peters AM, Paleolog E, Chapman PT, Elliott MJ, McCloskey R, et al. Reduction of chemokine levels and leukocyte traffic to joints by tumor necrosis factor alpha blockade in patients with rheumatoid arthritis. Arthritis Rheum 2000;43:38-47.

28 Antoni C, Dechant C, Hanns-Martin Lorenz PD, Wendler J, Ogilvie A, Lueftl M, et al. Open-label study of infliximab treatment for psoriatic arthritis: clinical and magnetic resonance imaging measurements of reduction of inflammation. Arthritis Rheum 2002;47:506-12.

29 Baeten D, Kruithof E, Van den Bosch F, Demetter P, Van Damme N, Cuvelier C, et al. Immunomodulatory effects of anti-tumor necrosis factor alpha therapy on synovium in spondylarthropathy: histologic findings in eight patients from an open-label pilot study. Arthritis Rheum 2001;44:186-95.

30 Baker BS, Swain AF, Valdimarsson H, Fry L. T-cell subpopulations in the blood and skin of patients with psoriasis. Br J Dermatol 1984;1 10:555-64

31 Gottlieb AB, Grossman RM, Khandke L, Carter DM, Sehgal PB, Fu SM, et al. Studies of the effect of cyclosporine in psoriasis in vivo: combined effects on activated T lymphocytes and epidermal regenerative maturation. J Invest Dermatol 1992;98:302-9

32 Ellis CN, Krueger GG. Treatment of chronic plaque psoriasis by selective targeting of memory effector T lymphocytes. N Engl J Med 2001;345:248-55.

33 Bata-Csorgo Z, Hammerberg C, Voorhees JJ, Cooper KD. Kinetics and regulation of human keratinocyte stem cell growth in short-term primary exvivo culture. Cooperative growth factors from psoriatic lesional T lymphocytes stimulate proliferation among psoriatic uninvolved, but not normal stem keratinocytes. J Clin Invest 1995:95:317-27.

34 Smeets TJM, Kraan MC, van Loon ME, Tak PP. TNF-alpha blockade reduces the synovial cell infiltrate early after initiation of treatment, but apparently not by induction of apoptosis in synovial tissue. Arthritis Rheum 2003;48:2155-62.

35 Hommes DW, van Dullemen HM, Levi M, van der Ende A, Woody J, Tytgat GN, et al. Beneficial effect of treatment with a monoclonal anti-tumor necrosis factor- $\alpha$ antibody on markers of coagulation and fibrinolysis in patients with active Crohn's disease. Haemostasis 1997:27:269-77.

36 Van Dullemen HM, van Deventer SJH, Hommes DW, Biil HA, Jansen J Tytgat GN, et al. Treatment of Crohn's disease with anti-tumor necrosis factor chimeric monoclonal antibody (cA2). Gastroenterology 1995;109:129-35.

37 Ten Hove T, Monffrans C, Peppelenbosch MP, van Deventer SJH. Infliximab treatment induces apoptosis of lamina propria T lymphocytes in Crohn's disease. Gut 2002;50:206-11.

38 Van den Brande JM, Braat $H$, van den Brink GR, Versteeg $H H$, Baver CA, Hoedemaker I, et al. Infliximab but not etanercept induces apoptosis in lamina propria T-lymphocytes from patients with Crohn's disease. Gastroenterology 2003:124:1774-85.

39 Moreland LW, Schiff MH, Baumgarter SW, Tindall EA, Fleischmann RM, Bulpitt KJ, et al. Etanercept therapy in rheumatoid arthritis. A randomized, controlled trial. Ann Intern Med 1999;130:478-86.

40 Mease PJ, Goffe BS, Metz J, VanderStoep A, Finck B, Burge DJ. Etanercept in the treatment of psoriatic arthritis and psoriasis: a randomised trial. Lancet 2000;356:385-90

41 Sandborn WJ, Hanauer SB, Katz S, Safdi M, Wolf DG, Baerg RD, et al. Etanercept for active Crohn's disease: a randomised, double-blind, placebocontrolled trial. Gastroenterology 2001;121:1088-94. 